Журнал«Герспективита інновації науки

(Серія«Гедагогіка», Серія«Гцихологія», Серія«Медицинв»

№4(4) 2021

УДК 159.922.27:[373.5.048:331.548]](045)

https://doi.org/10.52058/2786-4952 -2021-4(4)-376-386

Середа Олена Юріївна кандидат психологічних наук, старший викладач кафедри практичної психології, Інститут людини Університету імені Бориса Грінченка, бульвар Ігоря Шамо, 18/2, м. Київ, 02154, тел.: (044) 294-00-25, e-mail: elena0324ua@ gmail.com, https://orcid.org/0000-0003-2179-2740

\title{
ВПЛИВ СОЦІАЛЬНОГО ОТОЧЕННЯ НА ПРОФЕСІЙНИЙ ВИБІР ВИПУСКНИКІВ
}

Анотація. На сучасному етапі соціально-економічного розвитку України, в умовах реформування загальної середньої освіти і розбудови профільної школи, інтенсивних змін на ринку праці значно загострюється питання професійного самовизначення молоді, зокрема учнів старших класів. Ситуація завершення середньої освіти вимагає від старшокласників здійснити професійний вибір, що активізує потребу в самопізнанні, самоусвідомленні і саморозумінні. Однак на практиці з'ясовується, що професійне самовизначення молодих людей відбувається складно і виявляється відірваним від прагнень, інтересів і потреб самого старшокласника.

Проблема професійного самовизначення $є$ важливим і широко досліджуваним феноменом, який вивчається у зв'язку з життєвими перспективами особистості, як аспект соціального самовизначення (М.Р. Гінзбург, Є.І. Головаха, Д.І. Фельдштейн), пов'язаний з розвитком особистості, специфікою іiі смислового сприймання (Є.О. Клімов, М.С. Пряжніков, П.А. Шавір), у зв'язку зі спрямуванням і покликанням (В.П. Парамзін， К.К. Платонов， В.С. Чудновський). У сучасних дослідженнях проблеми професійного вибору старшокласників приділено увагу ознакам готовності старшокласників до професійного самовизначення (М.С.Скиба), особистісному потенціалу їхньої професійної самореалізації (С.Д. Максименко, Л.З. Сердюк), обумовленості професійної самореалізації особистісними цінностями (О.І. Пенькова), визначено технології побудови життєвих перспектив старшокласника (Н.Д. Володарська), а також зроблено акцент на творчу самореалізацію у толерантному освітньому просторі (С.П. Яланська, Н.М. Атаманчук). Дослідниками аналізується вплив чинників самодетермінації, автономії і самореалізації старшокласників на їхнє професійне самовизначення (K. Shorgen, L. Jaehoon, P. Panko).

Водночас у дослідженнях означеної проблеми бракує грунтовного вивчення впливу оточення на професійний вибір випускників, урахування якого практичними психологами і педагогами сприяло 6 створенню умов для активізації процесу професійного самовизначення і самореалізації старшокласників. Особливої ваги у цьому контексті набувають чинники, які 
сприяють самоактуалізації, а отже, відчуттю впевненості випускників у ситуації професійного вибору.

Ключові слова: професійний вибір, професійне самовизначення, психологічний вплив, протистояння психологічному впливу, вплив оточення, конфліктна ситуація.

Sereda Olena Yuriivna Candidate of Psychological Sciences, Senior Lecturer for the faculty of Psychology, Borys Grinchenko Kyiv University Institute of Human Sciences, I. Shamo Boule., 18/2, Kyiv, 02154, tel.: (044) 294-00-25, e-mail: elena0324ua@gmail.com, https://orcid.org/0000-0003-2179-2740

\section{IMPACT OF SOCIAL SURROUNDING ON GRADUATE'S OCCUPATIONAL CHOICE}

Abstract. On modern stages of Ukraine social and economic development, in terms of reforming general secondary education, development of profession- oriented schools and major changes on employment market, issues of professional selfdetermination became more acute than ever, especially for youth (senior high school students namely). After completing general secondary education, senior high school students are required to make an occupational choice which in turn stimulates the necessity of self-knowing, self-understanding and mindfulness. However, in real life professional self-determination of young people is becomes a challenging task, which is often out of touch with their actual interests, needs and ambitions.

Problem of professional self-determination is an important and widely researched phenomena, studied in connection with individual's project of life as an aspect of social self-determination (M.R. Ginzburg, Y.I. Golovakha, D.I. Feldstein), connected with development of one's identity and sensing particularities (Y.O. Klimov, M.S. Priazhnikov, P.A. Shavir) related with purposefulness and vocational aptitude (V.P. Paramzin, K.K. Platonov, V.Y. Chudnovskiy). Modern research on professional self-determination of senior school students focuses on signs of their readiness for professional self-determination (M.Y. Skyba), potential for personal self-realization, (S.D. Maksymenko, L.Z. Serdiuk) dependance of professional self-determination from personal values, (O.I. Pen'kova) defining mechanisms for development of senior school student's future life perspective (N.D. Volodarska) and emphasizes on creative self-realization within broadminded educational system (S.P. Yalanska, N.M. Atamanchuk). Researchers have analyzed the impact of senior school students; self-determination, self-sustainability and self-realization drivers on their occupational choices. (K. Shorgen, L. Jaehoon, P. Panko).

However, research of this issue still requires substantiated studies on impact of one's surrounding towards one's occupational choice, that (if taken into consideration by practicing psychologists and educationalists) would beneficially affect conditions for professional self-determination and self-realization of senior school students and 
Журнал«Герспективита інновації науки

(Серія«Гедагогіка», Серія «Гиихологія», Серія «Медицинв»

№4(4) 2021

catalyze the whole process itself. Specific attention in this context should be paid to aspects of promoting senior school students' self-actualization, thus giving a confidence boost for when they find themselves in the middle of making an occupational choice.

Keywords: occupational choice (professional choice), professional selfdetermination (occupational self-determination), psychological impact, resisting psychological impact, impact of surrounding, conflict situation.

Постановка проблеми. Психологічна суть процесу професійного самовизначення особистості, вплив на нього оточення можуть бути представлені 3 точки зору його внутрішніх механізмів, а також 3 точки зору процесуальних аспектів. Труднощі, які виникають у старшокласників у зв язку з прийняттям рішення щодо вибору майбутньої професії, часто спричинені внутрішніми мотиваційними конфліктами, недостатньою готовністю зробити вибір. Причинами можуть бути: несформованість певних особистісних характеристик, «незрілість» самої ситуації, недостатне іiі прояснення або брак необхідної інформації. Готовність до вибору професії, на нашу думку, обумовлена певним внутрішнім станом особистості старшокласника, що характеризується зрілістю особистісних структур, внаслідок конструктивної взаємодії комплексу соціальнопсихологічних чинників ситуації професійного визначення.

Самовизначення старшокласників означає не відокремлення від значущих дорослих, а об'єктивне визначення свого місця у світі дорослих. Поняття «самовизначення», тотожне поняттю «ідентичність» американського психоаналітика, автора теорії стадій психосоціального розвитку Е. Еріксона. Процес професійного самовизначення в юнацькому віці має глобальний характер. Він базується на внутрішніх психологічних властивостях, а реалізується у взаємодії із оточенням. Потреба старшокласника самовизначитися у різних сферах життя стає головною рушійною силою його подальшого розвитку. Активізуються процеси самопізнання, формування образу свого «Я», визначення своєї життєвої позиції, цінностей, світогляду. Їх інтенсивність надзвичайно посилюється саме в цей період життя.

Важливо дослідити феномен усвідомленого професійного визначення,

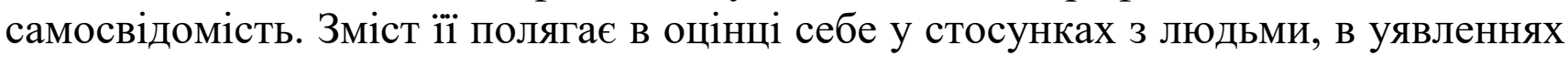
про бажане і реальне «Я», в усвідомленні своїх якостей. А найважливішими ознаками готовності старшокласника до професійного самовизначення $є$ : усвідомлення ситуації вибору, розуміння особливостей професій та об'єктивне співвіднесення із власними можливостями і інтересами, активна спрямованість на пошук засобів, необхідних для здійснення професійного самовизначення.

Аналіз останніх досліджень і публікацій. У сучасних дослідженнях проблеми професійного вибору старшокласників приділено увагу ознакам готовності старшокласників до професійного самовизначення (М.Є. Скиба), особистісному потенціалу їхньої професійної самореалізації (С.Д. Максименко, 
Л.3. Сердюк), обумовленості професійної самореалізації особистісними цінностями (О.І. Пенькова), визначено технології побудови життєвих перспектив старшокласника (Н.Д. Володарська), а також зроблено акцент на творчу самореалізацію у толерантному освітньому просторі (С.П. Яланська, Н.М. Атаманчук). Дослідниками аналізується вплив чинників самодетермінації, автономії і самореалізації старшокласників на їхнє професійне самовизначення (K. Shorgen, L. Jaehoon, P. Panko). Проблема психологічного впливу $є$ предметом уваги ряду публікацій О.В. Сидоренко, О.Г. Богуславської.

Мета статті - дослідження особливостей впливу соціального оточення на професійний вибір випускників та види протистояння такому впливу.

Виклад основного матеріалу. Досліджуючи проблему професійного самовизначення старшокласників, спираємось на факт зв'язку, взаємодії, єдності і взаємопроникнення структурних складових особистості, які позначаються на пізнавальній діяльності, навчанні, поведінці, вчинках, стосунках старшокласників. Ми провели дослідження для роз'яснення ситуації взаємодії зовнішніх впливів на внутрішню позицію старшокласників. Анкетування проводилось серед 40 випускників, що подавали документи на навчання у ВНЗ. Абітурієнти - вчорашні старшокласники, які вже остаточно визначились 3 вибором професії. Анкета складалась з запитань, які входять до таблиці видів психологічного впливу та протистояння впливові у процесі професійного самовизначення старшокласників i визначенням чинників зміни професії. Відповіді порівнювались між групами респондентів, які змінили свій професійний вибір та не змінили його.

Особливу увагу проблемі психологічного впливу приділили О.В. Сидоренко, О.Г. Богуславська. Використовуючи роботи вітчизняних та іноземних авторів, вона розробила класифікацію видів впливу та видів протистояння впливові оточення. Слідуючи за О.В. Сидоренко, під психологічним впливом розуміємо «вплив на стан, думки, почуття і дії іншої людини за допомогою психологічних засобів, а відповідно, протистояння чужому впливу - як супротив впливові іншої людини за допомогою психологічних засобів» [5, с. 125]. Випускники обирали ті види впливу, якого зазнали:

- Запевнення, навіювання (свідомий, аргументований вплив на іншу людину, який має на меті зміну їхніх суджень, відношення, намірів або рішень),

- Самопросування (відкритий прояв свідчень власної компетентності та кваліфікації для того, щоб отримати перевагу),

- Навіювання (свідомий, неаргументований вплив на людину з метою зміни ії стану та відношення до чогось),

Зараження (передача свого стану іншій людині, яка переймає цей стан або відношення),

- Спонукання до наслідування (здібність спонукати бути подібним собі, яка проявляється несвідомо або свідомо використана), 
Журнал«Герспективита інновації наукиљ

(Серія«Гедагогіка», Серія «Геихологія», Серія«Медицин»

№4(4) 2021

- ормування прихильності (розвиток в адресата позитивного відношення до себе як інструмента маніпуляції),

- Прохання (заклик задовільнити бажання адресата),

- Примус (вимога виконувати розпорядження ініціатора, підкріплене відкритими або завуальованими погрозами),

- Деструктивна критика (висловлювання зневажливих, образливих суджень про особистість людини, грубий осуд, висміювання дій, вчинків, слів),

- Ігнорування (усвідомлена неувага по відношенню до партнера, його висловів, дій),

- Маніпуляція (приховане від адресата спонукання до переживання певних станів, зміна відношення до чогось).

Та ті види психологічного протистояння впливу, які використовували:

- Контраргументація (свідома аргументована відповідь на спробу запевнення, яка заперечує чи оспорює аргументи).

- Конструктивна критика (підкріплене аргументами обговорення цілей, засобів або прагнень ініціатора, обгрунтування їх невідповідності меті і вимогам адресата).

- Енергетична мобілізація (супротив адресата спробам навіяти або передати йому певний стан, відношення, намір чи спосіб діiі).

- Творчість (створення нового, не відповідного зразку, прикладу).

- Уникання (налаштованість на уникнення будь-яких форм взаємодії 3 ініціатором).

- Психологічна самооборона (застосування мовних формул та засобів інтонації, які дозволяють зберегти самоконтроль та виграти час для осмислення подальших кроків).

- Ігнорування (усвідомлена неувага по відношенню до партнера, його висловів, дій).

- Конфронтація (відкрите та послідовне протиставлення адресатом своєї позиції та своїх вимог ініціатору взаємодії).

- Відмова (висловлювання адресатом своєї незгоди виконати прохання ініціатора взаємодії).

Під час дослідження нами визначено, що $67 \%$ випускників подають документи у ВНЗ не на ту професію, про яку мріяли. Отже, у період вибору професії учень старших класів - випускник визначав формування загальних поглядів на професійну діяльність, особистісних професійних смислів, коригував первинний романтичний професійний ідеал. Для детального розуміння мотивів зміни вибору професії розділили респондентів на дві групи:

1) випускники, які змінили професійний вибір;

2) випускники, які не змінили свій професійний вибір.

У цих групах ми отримали інформацію щодо сьогоднішньої реально-обраної професії: у випускників першої групи вона престижна (36,63\%) та має перспективу кар'єрного зросту (23,31\%), у випускників другої групи вона 
рідкісна (36,37\%), пов'язана із хобі та шкільними предметами $(27,27 \%)$; лише у $18,18 \%$ - престижна i 9,09\% - має перспективу кар'єрного зросту. Отже, у випускників, які не змінили свій професійний вибір, обрані професії більш пов'язані із особистісними нахилами, більше віддалені від суспільних пріоритетів, ніж у випускників, які змінили професійний вибір.

В дослідженні виявлена та підтверджена наявність у абітурієнтів індивідуальних ситуацій конфлікту, внутрішнього чи зовнішнього переживання, протистояння під час вибору професії (Таблиця 1).

Таблиияя 1

Види впливу, яких зазнають старшокласники під час вибору професії

\begin{tabular}{|c|c|c|c|}
\hline \multicolumn{2}{|c|}{$\begin{array}{c}\text { Для старшокласників, що змінили свій } \\
\text { вибір професії }\end{array}$} & \multicolumn{2}{|c|}{$\begin{array}{c}\text { Для старшокласників, що не змінили } \\
\text { свій вибір професії }\end{array}$} \\
\hline $\begin{array}{c}\text { Провідні види } \\
\text { впливу }\end{array}$ & $\begin{array}{c}\text { Кількість } \\
\text { позитивних } \\
\text { відповідей у \% }\end{array}$ & $\begin{array}{c}\text { Провідні види } \\
\text { впливу }\end{array}$ & $\begin{array}{c}\text { Кількість } \\
\text { позитивних } \\
\text { відповідей у \% }\end{array}$ \\
\hline Самопросування & 22,08 & Зараження & 18,4 \\
\hline Примус & 21,16 & Самопросування & 17,48 \\
\hline $\begin{array}{l}\text { Формування } \\
\text { прихильності }\end{array}$ & 14,26 & $\begin{array}{l}\text { Запевнення, } \\
\text { навіювання }\end{array}$ & 14,26 \\
\hline Маніпуляція & 14,26 & Наслідування & 13,34 \\
\hline Ігнорування & 10,12 & Зараження & 11,5 \\
\hline Наслідування & 9,66 & Маніпуляція & 10,12 \\
\hline $\begin{array}{l}\text { Деструктивна } \\
\text { критика }\end{array}$ & 3,68 & $\begin{array}{l}\text { Деструктивна } \\
\text { критика }\end{array}$ & 8,28 \\
\hline $\begin{array}{l}\text { Запевнення, } \\
\text { навіювання }\end{array}$ & 2,76 & $\begin{array}{l}\text { Формування } \\
\text { прихильності }\end{array}$ & 5,98 \\
\hline Прохання & 1,38 & Ігнорування & - \\
\hline Зараження & - & Прохання & - \\
\hline
\end{tabular}

Так, використовуючи вищезазначені засоби впливу, оточення брало участь у подоланні старшокласником неоднозначної ситуації професійного вибору. Види впливу мають різну інтенсивність у групах респондентів, які змінили та не змінили свій вибір. Очевидно значущим для зміни професії $є$ відкритий прояв своєї компетентності 3 боку оточення i вимога виконати розпорядження ініціатора. Респонденти обох груп майже не відчули на собі деструктивної критики, запевнень, навіювання чи прохання, зараження. Вплив, який відчула група респондентів з незміненим професійним вибором з боку оточення, більш однорідний за видами, прохання і ігнорування серед них відсутні. Такі види, як наслідування, маніпуляція, самопросування, зараження майже однакові в обох групах. Це говорить про амбівалентний характер частини видів впливу, які можуть мати як конструктивний, так і деструктивний характер взаємодії і впливу на ситуацію. Вважаємо, що має йтися не про принципову різницю між техніками взаємодіï, а про те, як той самий вплив може приймати різний характер наслідків 
Журнал«Герспективитаінновації науки»

(Серія«Гедагогіка», Серія«ГТихологія», Серія«Медицина»

№4(4) 2021

у рішенні щодо вибору професії. Отже, очевидною $є$ необхідність вивчати особистісні риси старшокласника.

Індивідуальну позицію старшокласників, яка безперечно позначалась на ситуації обговорення вибору професії, подано у Таблиці 2.

Таблиия 2

\section{Види протистояння впливу оточення}

\begin{tabular}{|c|c|c|c|}
\hline \multicolumn{2}{|c|}{$\begin{array}{c}\text { Для старшокласників, що змінили } \\
\text { свій вибір професії }\end{array}$} & \multicolumn{2}{|c|}{$\begin{array}{c}\text { Для старшокласників, що не змінили свій } \\
\text { вибір професії }\end{array}$} \\
\hline $\begin{array}{c}\text { Провідні види } \\
\text { протистояння впливу }\end{array}$ & $\begin{array}{c}\text { Кількість } \\
\text { позитивних } \\
\text { відповідей у \% }\end{array}$ & $\begin{array}{c}\text { Провідні види } \\
\text { протистояння впливу }\end{array}$ & $\begin{array}{c}\text { Кількість } \\
\text { позитивних } \\
\text { відповідей у \% }\end{array}$ \\
\hline $\begin{array}{l}\text { Психологічна } \\
\text { самооборона }\end{array}$ & 25,92 & Енергетична мобілізація & 18,36 \\
\hline $\begin{array}{l}\text { Енергетична } \\
\text { мобілізація }\end{array}$ & 23,76 & Контраргументація & 17,28 \\
\hline Творчість & 20,52 & $\begin{array}{l}\text { Психологічна } \\
\text { самооборона }\end{array}$ & 16,2 \\
\hline Уникання & 11,34 & Відмова & 14,04 \\
\hline Конфронтація & 11,34 & Творчість & 11,89 \\
\hline Контраргументація & 3,78 & Конструктивна критика & 11,43 \\
\hline Ігнорування & 3,34 & Конфронтація & 10,8 \\
\hline Відмова & - & Ігнорування & - \\
\hline $\begin{array}{l}\text { Конструктивна } \\
\text { критика }\end{array}$ & - & Уникання & - \\
\hline
\end{tabular}

Результати щодо провідних видів протистояння впливу оточуючих, які обирає для себе старшокласник під час прийняття рішення стосовно вибору професії, показують, що старшокласники, які не змінили свій професійний вибір, так само, як і ті старшокласники, що змінили свій вибір професії, зазвичай енергетично мобілізуються та використовують психологічну самооборону. Але інші види різняться, наприклад, респонденти, які не змінили професійний вибір, використовують відмову, а ті, що змінили, не використовують цей вид протистояння. Ймовірно, техніка реагування на вплив тісно пов'язана 3 особистісними рисами респондентів.

Отже, відбувається соціальна орієнтація особистості старшокласника, він починає розуміти себе як частину, елемент суспільства, вибирає свій майбутній соціальний статус та засіб його досягнення. В ході таких роздумів старшокласник розшукує унікальну формулу, що водночас висвітлила б йому сенс власного професійного існування та «задовільнила» вимоги об'єктивної реальності і соціальної ситуації. Такий механізм складається 3 «внутрішніх» та «зовнішніх» факторів, саме унікальна взаємодія міжподієвих зав'язків зумовлює професійний вибір старшокласника, міру відхилення реально-обраної професії від омріяної та професійного профілю особистості. Адже старшокласник активно 
спілкувався, ліквідуючи брак інформації про світ професій загалом, можливості власної адаптації до них, про себе, свої можливості та здібності, і отримував зворотній зв'язок від світу. Він шукав «свою» професію, цінності якої відображають його внутрішні позиції та потреби. Відбулося, 3 одного боку, величезне розширення знань про кількість професій, напрямів діяльності, можливостей особистісного зростання, а з іншого - зростали тиск оточення і вага життєтворчого незворотного рішення. Здобуття бажаної професії конкурувало із здобуттям професії із більшим заробітком та іншими об'єктивними реаліями сьогодення.

Ми виявили види впливу на старшокласника під час вибору професії та стратегії його протистояння, а саме: самопросування, примус, зараження, формування прихильності, запевнення, навіювання, маніпуляція. Однак, продуктивність дослідження виключно конфліктних ситуацій сумнівна. Так, старшокласники, що змінили свій вибір професіі, не вважають вибір усвідомленим $(54,55 \%)$, і 72,73\% 3 них не впевнені у своїх можливостях посправжньому оволодіти обраною професією. Вони, не маючи мотивації, розраховують на силу волі $(81,82 \%)$, знання $(68,42 \%)$ та гроші $(27,27 \%)$. У той час 94,73\% старшокласників, що не змінили свого рішення, впевнені у своєму виборі, який є усвідомленим та підкріпленим знаннями $(68,42 \%)$ і мотивацією (47,37\%). Таким чином, маємо розглядати ситуацію у широкому часовому вимірі та міжподієвому зв'язку.

Отже, фактичну проблему перевантаження ринку праці спеціалістами певної галузі, браком кадрів у інших сферах, не працевлаштованих спеціалістів, спеціалістів, що не люблять і не поважають свою спеціальність, тощо неможливо вирішити звичайним шляхом владнання конфлікту. Очевидно, головною проблемою старшокласників $є$ життєве самовизначення, саме зараз перед молоддю гостро постає питання: ким бути? Його вирішення залежить від психологічної та соціальної зрілості, готовності оволодіти знаннями, що стосуються вузької професійної спрямованості. Психологічна готовність опанувати певну спеціальність не є простим наслідком фізичного та соціального розвитку старшокласника. Фізичний стан організму, соціальний статус, соціально-політичні причини, економічний стан старшокласника, загальні процеси та тенденції суспільства, де визріває особистість, суттєво коригують, часом повністю змінюють життєві плани, але не змінюють професійне покликання, схильності та здібності старшокласника. Ці складові утворюють систему професійних цінностей школяра, які втілюються в образ омріяної професіï.

Для визначення чинників зміни професії за С.О. Клімовим, ми запропонували респондентам обрати серед визначених [2]. Серед типів обставин, які вплинули на професійний вибір, випускники найчастіше позначали позицію старших членів сім’і, здібності і вміння, схильності. Позиція старших членів сім’ї - 20\%, здібності, вміння - 19,09\%, схильності - 19,09\%, особистісні 
професійні плани - 18,18\%, рівень очікувань суспільного визнання - 6,36\%, позиція однолітків $-4,55 \%$, інформованість $-1,82 \%$, позиція вчителів - 0 , інше 10,91\%. Важливо зазначити, позиція вчителів, позиція однолітків, інформованість не виявились надто значущими, а пункт «інше» має великий відсоток. Швидкий темп сучасності і динаміка суспільних процесів вносять явні коригування в очікування професійної спрямованості молоді. Тому вважаємо актуальним дослідження соціально-психологічних чинників професійного самовизначення сучасних старшокласників, де зможемо розкрити фактори професійного самовизначення більш детально і широко.

Досліджуючи професійний вибір школярів, О.О. Бодальов зробив висновок, що «не дивлячись на деякі розбіжності у мотивації вибору майбутньої професії, у восьмикласників чітко визначається спільна характерна особливість професійних намірів. Реальний вибір своєї майбутньої професії у більшості з них відповідає романтичній мрії» [1, c.43]. Прагнучи професійного самовизначення, старшокласник вийшов за межі шкільної освіти у пошуку нових видів і форм спілкування (ходив на виставки, у музеї та театри, відвідував презентації, гуртки, курси, мандрував, зважав на соціальні ролі, моду, рекламу), але при остаточному прийнятті рішення стосовно вибору професії залишився обмеженим близьким колом спілкування - батьками, однолітками, родичами, їх очікуваннями i стереотипами. Як показали результати нашого опитування, значну роль у виборі професії для старшокласника відіграло спілкування з батьками $(53,28 \%)$, друзями $(39,96 \%)$, вчителями i родичами $(26,64 \%)$, коханою людиною та, навіть, випадковими співрозмовниками $(23,31 \%)$.

Оточення передало старшокласнику досвід ставлення до обраної спеціальності через своє суб'єктивне ставлення до неї та самого старшокласника, демонстрацію образів спеціалістів даної сфери, розповідь анекдотів та випадків, через кількість згадок про обрану спеціальність у буденних розмовах як про потрібну та непотрібну, добре або погано оплачувану, престижну або ні, про що чув старшокласник протягом усього життя. Обговорювалися певні особливості матеріальних можливостей тощо. Бажання старшокласника стати спеціалістом у омріяній сфері коригувалося та змінювалося.

Висновки. Дослідження виявило, що чинники ситуації професійного самовизначення, які визначають взаємодію старшокласника з оточуючим світом, a, відповідно, розвиток подій, тактик і стратегій, отже конструктивність прийняття рішення, мають бути вивчені з позиції отриманого досвіду, а не аналізу ситуації вибору як такої. 3 психологічної точки зору ситуативним фактором обов'язково $\epsilon$ наявність «третьої сили» як умови ефективності комунікації і прийняття рішень. Нею може бути вплив оточення, особливість поведінки співрозмовника, умови, передбачення тощо. Так, професійний вибір старшокласника вважаємо унікальним кроком у майбутнє доросле життя, якому передує безліч взаємопов'язаних подій. Кожна 3 них відбита у його пам'яті, утворюючи механізм досвіду стосовно вибору професії. Особистісні риси 
старшокласника визначають адаптивність до об'єктивних зовнішніх чинників. Продуктивним вважаємо подальший розгляд теми чинників професійного самовизначення старшокласників через призму сенсу, яким вони самі наділяють цей процес.

Виходячи 3 отриманих результатів, актуальним i новим вважаємо подальший розгляд типів i соціально-психологічних чинників професійного вибору старшокласника, їх взаємопов'язаність та взаємопроникнення, розкриття специфіки впливу оточуючого середовища та адаптивність до нього старшокласників. Ситуація професійного вибору старшокласників є складною, тонкою, неоднозначною. Це не просто співвідношення компонентів, що складають професійне самовизначення старшокласників. Для цього співвідношення характерні їх взаємопроникнення та переходи одного в інше. Професійне самовизначення кожного старшокласника має свою особливу логіку набуття. Необхідним $є$ вивчення думки старшокласників щодо чинників впливу на їх професійний вибір.

\section{Jimepamypa:}

1. Бодалев А. А. Психология о личности. Москва: МГУ, 1986. 188 с.

2. Климов Е. А. Психология профессионального самоопределения / Климов Е. А. Москва: Академия, 2004. 304 с.

3. Пенькова О. І. Ціннісні аспекти самореалізації особистості. Актуальні проблеми психологї: Збірник наукових пращь Інституту психологї імені Г. С. Костюка НАПН України. Київ-Житомир: Вид-во ЖДУ імені I. Франка, 2018. Т. VI. Вип. 14. С. 201-207.

4. Сердюк Л. 3. Психологія мотивації учіння майбутніх фахівців: системносинергетичний підхід. Київ: Університет «Україна», 2012. 323 с.

5. Сидоренко Е. В. Личностное влияние и противостояние чужому влиянию. Психологические проблемы самореализации личности. Санкт-Петербург, 1997. 462 с.

6. Shorgen K. A., Jaehoon L., Panko P. An Examination of the Relationship between Postschool Outcomes and Autonomy. Psychological Empowerment, and Self-Realization. The Journal of Special Education, 2016. 51, Is. 2. P. 115-124. URL: http://doi.org/10.1177/0022466916683171 (дата звернення: 18.03.2028)

7. Sikura A. Y., Plisko V. I., Baliuk A. S. Ways of selecting talented master-degree students for research work. Science and Education. 2017. № 8. P. 127-133. DOI: https://doi.org/10.24195/24144665-2017-8-1912 (дата звернення: 21.09.2020)

\section{References:}

1. Bodalev, A. A. (1986). Psihologija o lichnosti [Psychology of personality]. Moskva: MGU [in Russian].

2. Klimov, E. A. (2004). Psihologija professional'nogo samoopredelenija [Psychology of professional self-determination]. Moskva: Akademija [in Russian].

3. Pen'kova, O. I. (2018). Cinnisni aspekti samorealizaciï osobistosti [Value aspects of selfrealization of the individual]. Aktual'ni problemi psihologii - Actual problems of psychology, 14, 201-207 [in Ukrainian].

4. Serdjuk, L. Z. (2012). Psihologija motivaciï uchinnja majbutnih fahivciv: sistemnosinergetichnij pidhid [Psychology of motivation of future specialists: system-synergetic approach]. Kiïv: Universitet «Ukraïna» [in Ukrainian]. 
5. Sidorenko, E. V. (1997). Lichnostnoe vlijanie $i$ protivostojanie chuzhomu vlijaniju. Psihologicheskie problemy samorealizacii lichnosti [Personal influence and opposition to another's influence. Psychological problems of personal self-realization]. Sankt-Peterburg, [in Russian].

6. Shorgen K. A., Jaehoon L., Panko P. An Examination of the Relationship between Postschool Outcomes and Autonomy. Psychological Empowerment, and Self-Realization. The Journal of Special Education, 2016. 51, Is. 2. P. 115-124. URL: http://doi.org/10.1177/0022466916683171 (дата звернення: 18.03.2028)

7. Sikura A. Y., Plisko V. I., Baliuk A. S. Ways of selecting talented master-degree students for research work. Science and Education. 2017. № 8. P. 127-133. DOI: https://doi.org/10.24195/24144665-2017-8-1912 (дата звернення: 21.09.2020) 